\title{
PENGELOMPOKAN TINGKAT KRIMINALITAS DENGAN METODE AGGLOMERATIVE DAN K-MEANS SERTA PEUBAH PENCIRINYA
}

\author{
Nyoman Gde Prajnawiweka Ratmasa Taram ${ }^{1 \S}$, I Komang Gde Sukarsa ${ }^{2}$ I Gusti Ayu Made Srinadi ${ }^{3}$ \\ ${ }^{1}$ Program studi Matematika, Fakultas MIPA - Universitas Udayana [Email: prajna.wiweka@gmail.com] \\ ${ }^{2}$ Program studi Matematika, Fakultas MIPA - Universitas Udayana [Email: gedesukarsa@unud.ac.id] \\ ${ }^{3}$ Program studi Matematika, Fakultas MIPA - Universitas Udayana [Email: srinadi@unud.ac.id] \\ ${ }^{\S}$ Corresponding Author
}

\begin{abstract}
The purpose of this research is it define the classification of crime rate based on the type of crime and its characterization variable. The data used in this research are secondary data in form of data on the number of crime rates based on the type of crime in 32 regional police in the province with 12 variables. This research is used Agglomerative and K-Means method along with Biplot Analysis. The result shows that there are three classification based upon Single Linkage as the best method which each characteristic of every classification is the crime of family abuse, crime of minor mistreatment and crime of corruption.
\end{abstract}

Keywords : Classification, Agglomerative, K-Means, Biplot Analysis, Single Linkage, Crime

\section{PENDAHULUAN}

Tingkat kriminal adalah skala atau gambaran profil yang dapat mengukur kriminalitas gerombol (masyarakat) di suatu daerah. Semakin tinggi angka kriminalitas menunjukkan semakin banyak tindak kejahatan pada masyarakat yang merupakan indikasi bahwa masyarakat merasa semakin tidak aman. Dalam analisis statistika, indikator-indikator tersebut dinyatakan sebagai variabel. Untuk meringkas data dengan peubah banyak, dapat digunakan analisis gerombol untuk mengelompokkan obyek-obyek pengamatan menjadi beberapa gerombol berdasarkan pengukuran peubah-peubah yang diamati.

Gerombol atau cluster dapat diartikan sebagai kelompok, pada dasarnya analisis gerombol akan menghasilkan sejumlah kelompok (gerombol). Analisis gerombol merupakan salah satu metode dalam analisis statistika peubah ganda yang digunakan untuk mengelompokkan obyek-obyek ke dalam suatu gerombol berdasarkan karakteristik yang dimiliki, sehingga obyek-obyek dalam satu kelompok memiliki ciri-ciri yang lebih homogen dibandingkan dengan obyek dalam gerombol lain. Untuk mendapatkan gerombol yang sehomogen mungkin, maka yang digunakan sebagai dasar untuk mengelompokkan adalah kesamaan skor nilai yang dianalisis (Gudono, 2011).

Secara umum terdapat dua metode pengelompokan dalam analisis gerombol yaitu metode hierarki dan metode non-hierarki. Metode penggerombolan berhierarki dibedakan menjadi dua metode yaitu metode penggabungan (agglomerative) dan metode pemisah (divisive). Dalam metode agglomerative terdapat beberapa ukuran jarak antar gerombol, antara lain jarak minimum antar gerombol atau pautan tunggal (single linkage), jarak maksimum antar gerombol atau pautan lengkap (complete linkage) dan rata-rata dari semua jarak atau pautan rataan (average lingkage) (Everitt, 2011).

Pengelompokan menggunakan metode single linkage dengan melihat jarak antar gerombol yang ada kemudian memilih jarak yang paling dekat atau jarak minimum. Menurut Johnson dan Wichern (2007) jarak minimum antara gerombol $i$ dengan gerombol $w$ dan gerombol $j$ dengan gerombol $w$ dapat ditulis sebagai 


$$
D_{(i j) w}=\min \left\{d_{i w}, d_{j w}\right\}
$$

Pada metode complete linkage, jarak antar gerombol ditentukan oleh jarak terjauh atau jarak maksimum antara dua obyek dalam gerombol yang berbeda. Menurut Johnson dan Wichern (2007) jarak maksimum antara gerombol $i$ dengan gerombol $w$ dan gerombol $j$ dengan gerombol $w$ dapat ditulis sebagai:

$$
D_{(i j) w}=\max \left\{d_{i w}, d_{j w}\right\}
$$

dengan $d_{i w}$ dan $d_{j w}$ masing-masing adalah jarak terjauh antara gerombol $i$ dengan gerombol $w$ dan juga gerombol $j$ dan gerombol $w$.

Pengelompokan dengan metode average linkage dengan menghitung jarak antara dua gerombol yang disebut sebagai jarak rata-rata antara semua anggota dalam satu gerombol dengan semua anggota gerombol lain. Jarak ratarata antara gerombol $(i j)$ dengan gerombol lain yaitu $w$ dapat ditulis sebagai :

$$
D_{(i j) w}=\frac{\sum_{n} \sum_{k} d_{n k}}{N_{(i j)} N_{w}}
$$

dengan $d_{n k}$ adalah jarak obyek $n$ (pada gerombol $i$ dan gerombol $j$ dengan gerombol tersebut membentuk gerombol tunggal $(i j)$, dengan obyek $k$ pada gerombol $w$, sedangkan $N_{(i j)}$ dan $N_{w}$ berturut-turut merupakan jumlah obyek dalam gerombol $(i j)$ dan $w$

Metode pengelompokkan non hierarki digunakan jika banyaknya kelompok yang akan dibentuk sudah diketahui sebelumnya. Metode non hierarki sering disebut sebagai metode $\mathrm{k}$ means. Prosedur pada metode non hierarki dimulai dengan memilih pusat kelompok (centroid) kemudian menentukan jarak setiap objek dengan setiap centroid. Perhitungan jarak minimum antar objek dengan centroid menggunakan persamaan jarak Euclidean.

Tujuan penelitian ini adalah untuk mengetahui metode pengelompokan terbaik diantara metode single linkage, complete linkage, average linkage dan k-means serta perubah penciri dari kelompok yang dihasilkan.

Metode pengelompokan yang baik mempunyai nilai simpangan baku dalam kelompok $\left(s_{w}\right)$ yang minimum dan nilai simpangan baku antar kelompok $\left(s_{b}\right)$ yang maksimum (Barakbah \& Kohei, 2004). Menurut Bunkers, et al (1996) rumus simpangan baku dalam kelompok adalah sebagai berikut :

$$
s_{w}=\frac{1}{K} \sum_{k=1}^{K} s_{k}
$$

dengan

$K \quad$ : Banyaknya kelmpok yang terbentuk

$s_{k} \quad$ : Simpangan baku kelompok ke- $k$

Jika diberikan gerombol $D_{k}$, dimana $k=$ $1,2, \ldots, k$ dan setiap gerombol memiliki anggota $x_{i}$, dimana $i=1,2, . ., n$ dan $n$ adalah jumlah anggota dari setiap gerombol, dan $\bar{x}_{k}$ adalah rata-rata dari gerombol $k$ maka untuk mencari nilai $s_{k}$ digunakan rumus sebagai berikut:

$$
s_{k}=\sqrt{\frac{1}{n-1} \sum_{k=1}^{n}\left(x_{i}-\bar{x}_{k}\right)^{2}}
$$

Jika terdapat rata-rata variabel dalam setiap gerombol $k\left(\bar{X}_{k}\right)$ maka komponen setiap gerombol berbeda dan simpangan baku antar kelompok $\left(s_{b}\right)$ dapat dirumuskan berikut :

$$
s_{b}=\left[\frac{1}{(K-1)} \sum_{k=1}^{K}\left(\bar{X}_{k}-\bar{X}\right)^{2}\right]^{1 / 2}
$$

dengan

$K=$ Banyak kerompok yang terbentuk

$\bar{X}_{k} \quad=$ Rataan kelompok ke- $k$

$\bar{X} \quad=$ Rataan keseluruhan kelompok

Menurut Barakbah dan Kohei (2004), pengelompokan yang baik memiliki nilai $s_{w}$ minimum dan $s_{b}$ maksimum dapat dirumuskan sebagai berikut :

$$
s=\frac{s_{w}}{s_{b}} \times 100 \%
$$

Analisis biplot merupakan dua dimensi dari suatu matriks data $X$ yang menampilkan titik untuk masing-masing vector pengamatan $n$ bersama dengan titik untuk masing-masing $p$ peubah (Rencher, 2002). Dengan demikian biplot dibangun dari suatu matriks data $X$, dengan masing-masing baris mewakili objek penelitian dan masing-masing kolom mewakili suatu peubah.

$$
{ }_{n} X_{p}=\left[\begin{array}{ccc}
X_{11} & \cdots & X_{1 p} \\
\vdots & \ddots & \vdots \\
X_{n 1} & \cdots & X_{n p}
\end{array}\right]
$$

Matriks $X$ memuat peubah-peubah yang akn diteliti sebanyak $p$ dan objek penelitian ebanyak $n$. 
Analisis Biplot didasarkan pada penguraian nilai singular. Suatu matriks ${ }_{n} X_{p}$ yang dapat di uraikan menjadi :

$$
{ }_{n} X_{p}=U_{n \times r} L_{r \times r} A^{\prime}{ }_{r x p}
$$

Menurut Jollife (2002), terdapat dua nlai $\alpha$ yang digunakan untuk medefinisikan $G=U L^{a}$ dan $H^{\prime}=L^{1-a} A^{\prime}$, yaitu $\alpha=0$ dan $\alpha=1$. Kedua nilai $\alpha$ tersebut berguna dalam interpretasi biplot.

a. Parameter $\alpha=0$

Jika $\alpha=0$, maka $G=U L^{a}$ dan $H^{\prime}=L^{1-a} A^{\prime}$, ini berarti bahwa

$$
\begin{aligned}
X^{\prime} X & =\left(G H^{\prime}\right)^{\prime}\left(G H^{\prime}\right) \\
& =H G^{\prime} G H^{\prime} \\
& =H U^{\prime} U H^{\prime} \\
& =H H^{\prime}
\end{aligned}
$$

Secara keseluruhan pemilihan $\alpha=0$, akan memberikan gambaran mengenai jarak antara kolom dan akan memberikan informasi mengenai keragaman peubah, hubungan antara peubah serta mendapatkan informasi mengenai pola objek.

b. $\alpha=1$

Jika $\alpha=0$, maka $G=U L^{a}$ dan $H^{\prime}=L^{1-a} A^{\prime}$, ini berarti bahwa

$$
\begin{aligned}
X^{\prime} X & =\left(G H^{\prime}\right)\left(G H^{\prime}\right)^{\prime} \\
& =G H^{\prime} H G^{\prime} \\
& =G A^{\prime} A G^{\prime} \\
& =G G^{\prime}
\end{aligned}
$$

Secara keseluruhan, pemilihan $\alpha=1$, akan memberikan gambaran tentang jarak antara pasangan baris, sehingga lebih memfokuskan falam penggambaran kedekatan objek2 daripada keragaman dan hubungan peubah.

\section{METODE PENELITIAN}

Jenis data yang digunakan dalam penelitian ini adalah data kuantitiatif, yaitu data yang berupa angka-angka dan dapat dihitung. Data yang dikumpulkan adalah data sekunder yang diperoleh dari Badan Pusat Statistik (BPS) berupa data jumlah kriminalitas menurut jenis kejahatan pada tahun 2016 yang terdiri dari 32 Polda di provinsi. Variabel yang digunakan dalam penelitian ini merupakan faktor-faktor yang turut mempengaruhi tingkat kriminalitas meliputi jumlah kejahatan pembunuhan (X1), jumlah kejahatan penganiayaan berat (X2), jumlah kejahatan penganiayaan ringan (X3), jumlah kejahatan KDRT (X4), jumlah kejahatan perkosaan (X5), jumlah kejahatan pencabulan (X6), jumlah kejahatan penculikan (X7), jumlah kejahatan pencurian (X8), jumlah kejahatan narkotika dan psikotropika (X9), jumlah kejahatan penipuan (X10), jumlah kejahatan penggelapan (X11), dan jumlah kejahatan korupsi (X12).

Tahapan analisis yang digunakan dalam penelitian ini adalah sebagai berikut.

1. Penyiapan data

Pada tahap penyiapan data, hal yang perlu diperhatikan adalah satuan pengukuran untuk masing-masing variabel. Bila variabel-varibael yang diperoleh memiliki satuan pengukuran yang sama maka data tidak perlu distandarisasi.

2. Melakukan analisis gerombol

Pada tahap ini meliputi :

a. Mengukur jarak kemiripan

Pada tahap ini dilakukan pengukuran kemiripan objek dari data jumlah tingkat kriminalitas menurut jenis kejahatan pada 32 Polda di provinsi menggunakan jarak Euclidean dengan menggunakan persamaan

$$
d_{i j}=\sqrt{\sum_{k=1}^{p}\left(x_{k i}-x_{k j}\right)^{2}}
$$

Semakin kecil jarak Euclidean maka semakin mirip kedua variabel.

b. Menentukan jumlah kelompok yang akan di bentuk.

Banyak kelompok yang dihasilkan akan ditentukan berdasarkan tingkat kriminalitasnya. Menurut Mustofa (2011) tingkat kriminalitas dibagi menjadi tiga, yaitu tingkat kriminalitas rendah, tingkat kriminalitas sedang, dan tingkat kriminalitas tinggi.

c. Metode pengelompokkan yang akan digunakan.

Metode yang akan digunakan dalam penelitian ini adalah metode Agglomerative dan metode K-Means. Dalam metode Agglomerative akan digunakan metode pautan yang terdiri dari 
pautan tunggal (Single Linkage), pautan lengkap (Complete Linkage) dan pautan rataan (Average Lingkage).

3. Pemilihan metode terbaik

Pada tahap ini akan dilakukan pemilihan metode terbaik. Hasil dari tahap ini akan dilanjutkan dengan metode biplot untuk mengetahui peubah pencirinya.

4. Melakukan analisis biplot

Pada tahap ini meliputi :

a. Penentuan parameter

Sesuai dengan tujuan penelitian, maka $\alpha$ yang dipilih adalah $\alpha=0$, karena pemilihan $\alpha=0$ memberikan kesesuaian optimal untuk data dan keragaman. Pada $\alpha$ $=0$, tampilan biplot mampu menggambarkan keragaman peubah, hubungan antar peubah serta mendapatkan informasi mengenai objek, sehingga sesuai dengan tujuan penelitian.

b. Penguraian nilai singular

Melalui penguraian nilai singular akan diperoleh:

- Vektor-vektor eigen yang memberikan informasi mengenai peubah-peubah yang digunakan.

- Nilai-nilai eigen yang berisi informasi tentang keragaman komponenkomponen Bersama dari masing-masing vektor eigen.

- Koordinat-koordinat dimensi peragaan biplot.

c. Pembuatan plot

Pada pembuatan plot ini akan menunjukkan presentase banyaknya informasi yang bias dijelaskan oleh biplot atau nilai kelayakan analisis biplot.

5. Interpretasi Hasil.

\section{HASIL DAN PEMBAHASAN}

\subsection{Data Penelitian}

Data yang digunakan dalam penelitian ini adalah data sekunder yang diambil dari Badan Pusat Statistik (BPS) berupa data jumlah kriminalitas menurut jenis kejahatan pada tahun 2016. Peneliti menggunakan 32 provinsi tiap Polda sebagai objek amatan dengan jenis kejahatan yang diamati sebanyak 12 amatan terangkum dalam lampiran 1. Satuan pengukuran yang digunakan untuk menyatakan jumlah dari setiap jenis kejahatan yang terjadi adalah sama maka tidak perlu dilakukan standarisasi data.

Jumlah kejahatan pembunuhan maksimum terjadi pada provinsi Sumatera Utara, sedangkan jumlah kejahatan pembunuhan minimum terjadi pada provinsi Papua Barat. Jumlah kejahatan pembunuhan berat maksmimum terjadi pada Provinsi Sumatera Utara sedangkan jumlah kejahatan pembunuhan berat minimum terjadi pada Provinsi Bali.

\subsection{Pengukuran Jarak Euclidean}

Berdasarkan data yang diperoleh, dengan menggunakan persamaan jarak Euclidean, hasil perhitungan jarak Euclidean antara Provinsi Aceh dengan Provinsi Sumatera Utara adalah 5.929,24, sedangkan jarak Euclidean Provinsi Aceh dengan Provinsi Sumatera Barat adalah 1.064,17. Hal ini menunjukkan bahwa Provinsi Aceh memiliki karakteristik yang lebih mirip dengan Provinsi Sumatera Barat karena jarak Euclidean Provinsi Aceh lebih dekat dengan Provinsi Sumatera Barat dibandingkan dengan jarak Euclidean Provinsi Aceh ke Provinsi Sumatera Barat.

Demikian pula untuk penafsiran jarak Euclidean provinsi lainnya, semakin kecil jarak kedua provinsi maka akan semakin mirip karakteristik dari kedua objek tersebut. Berdasarkan perhitungan yang diperoleh, jarak terdekat adalah 228,17 yang merupakan jarak antara Provinsi Maluku Utara (nomor urut 30) dan Provinsi Papua Barat (nomor urut 31).

\subsection{Pengelompokan dengan Metode Single Linkage}

Proses penggabungan dengan metode pautan Single Linkage dengan melihat jarak antar gerombol yang ada kemudian memilih jarak minimum. Berdasarkan jarak penggabungan antara Provinsi Maluku Utara (nomor urut 30) dan Provinsi Papua Barat (nomor urut 31) maka diperoleh jarak antar gerombol $(30,31)$ dengan gerombol lain menggunakan persamaan (2.2). 
Sebagai contoh diberikan perhitungan antara gerombol $(30,31)$ dengan gerombol 1,2 dan 3 .

$d_{(3031) 1}=$

$\min \left\{d_{301}, d_{3111}\right\}=$

$\min \{2.624,32,2.477,76\}=2.477,76$

$d_{(3031) 2}=$

$\min \left\{d_{302}, d_{313}\right\}=\min \{7.983,40,7.904,59\}=$

$7.904,59$

$d_{(3031) 3}=$

$\min \left\{d_{303}, d_{314}\right\}=\min \{2.971,25,2.797,79\}=$

$2.797,76$

Setelah beberapa provinsi bergabung selanjutnya dilakukan lagi perhitungan jarak sehingga terbentuk matriks jarak yang telah tereduksi. Demikian proses dilakukan sehingga seluruh provinsi membentuk tiga gerombol seperti diultrasikan dalam dendogram pada gambar 1.

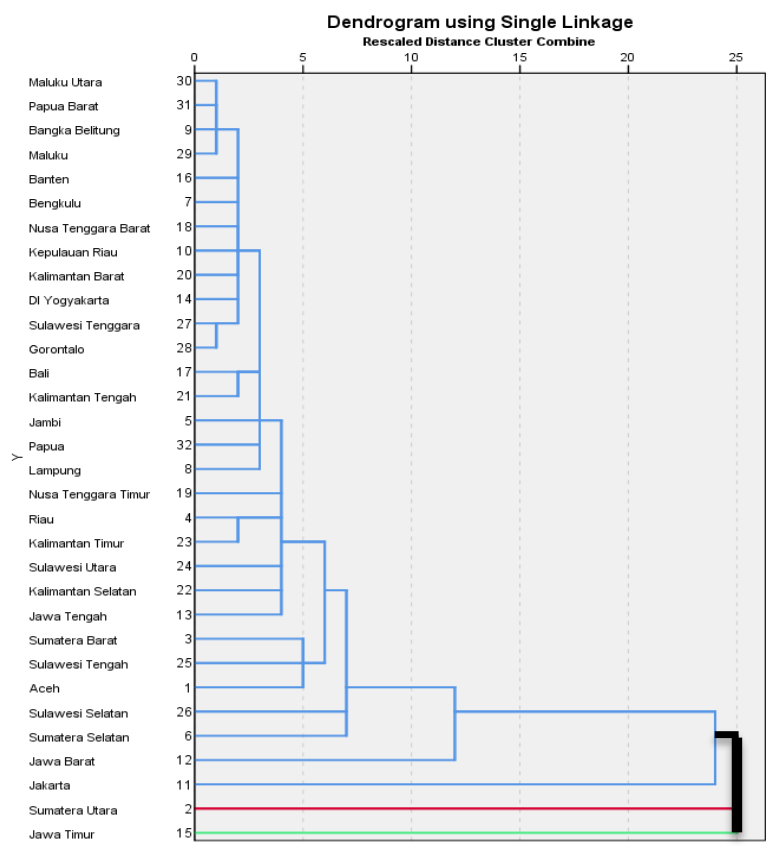

Gambar 1. Dendogram Single Linkage

Berdasarkan gambar 1 dibentuk tabel 1 menyajikan hasil pengelompokan provinsi berdasarkan jenis kejahatan dengan metode Single Linkage.
Tabel 1. Pengelompokan Provinsi dengan Metode Single Linkage

\begin{tabular}{|c|l|l|}
\hline Kelompok & \multicolumn{2}{|c|}{ Anggota Kelompok } \\
\hline \multirow{4}{*}{} & Aceh & Nusa Tenggara Barat \\
\cline { 2 - 3 } & Sumatera Barat & Nusa Tenggara Timur \\
\cline { 2 - 3 } & Riau & Kalimantan Barat \\
\cline { 2 - 3 } & Jambi & Kalimantan Tengah \\
\cline { 2 - 3 } & Sumatera Selatan & Kalimantan Selatan \\
\cline { 2 - 3 } & Bengkulu & Kalimantan Timur \\
\cline { 2 - 3 } & Lampung & Sulawesi Utara \\
\cline { 2 - 3 } & Bangka Belitung & Sulawesi Tengah \\
\cline { 2 - 3 } & Kepulauan Riau & Sulawesi Selatan \\
\cline { 2 - 3 } & Jakarta & Sulawesi Tenggara \\
\cline { 2 - 3 } & Jawa Barat & Gorontalo \\
\cline { 2 - 3 } & Jawa Tengah & Maluku \\
\cline { 2 - 3 } & DI Yogyakarta & Maluku Utara \\
\cline { 2 - 3 } & Banten & Papua Barat \\
\cline { 2 - 3 } & Bali & Papua \\
\hline 2 & Sumatera Utara & \\
\hline 3 & Jawa Timur & \\
\hline Suman & Damala & \\
\hline
\end{tabular}

Sumber : Data Sekunder (2018), diolah

\subsection{Pengelompokan Dengan Metode Complete Linkage}

Pada metode Complete Linkage, proses penggabungan dilakukan dengan objek yang mempunyai jarak maksimum atau jarak terjauh antar objek. Untuk membentuk gerombol pada metode ini dimulai dengan jarak Euclidean yang paling dekat antar provinsi berdasarkan lampiran 2 adalah Provinsi Maluku Utara (nomor urut 30) dan Provinsi Papua Barat (nomor urut 31) maka diperoleh jarak antar gerombol (30,31). Berikut perhitungan jarak maksimum gerombol $(30,31)$ dengan gerombol 1,2 dan 3 sebagai contoh.

$d_{(3031) 1}=$ $\max \left\{d_{301}, d_{3111}\right\}=$ $\min \{2.624,32,2.477,76\}=2.624,32$

$d_{(3031) 2}=$ $\max \left\{d_{302}, d_{313}\right\}=\min \{7.983,40,7.904,59\}=$ $7.983,40$

$d_{(3031) 3}=$ $\max \left\{d_{303}, d_{314}\right\}=\min \{2.971,25,2.797,79\}=$ $2.971,25$

Demikian seterusnya, perhitungan jarak maksimum dilakukan sehingga seluruh provinsi tergabung menjadi tiga gerombol seperti diilustrasikan di dalam gambar 2 . 


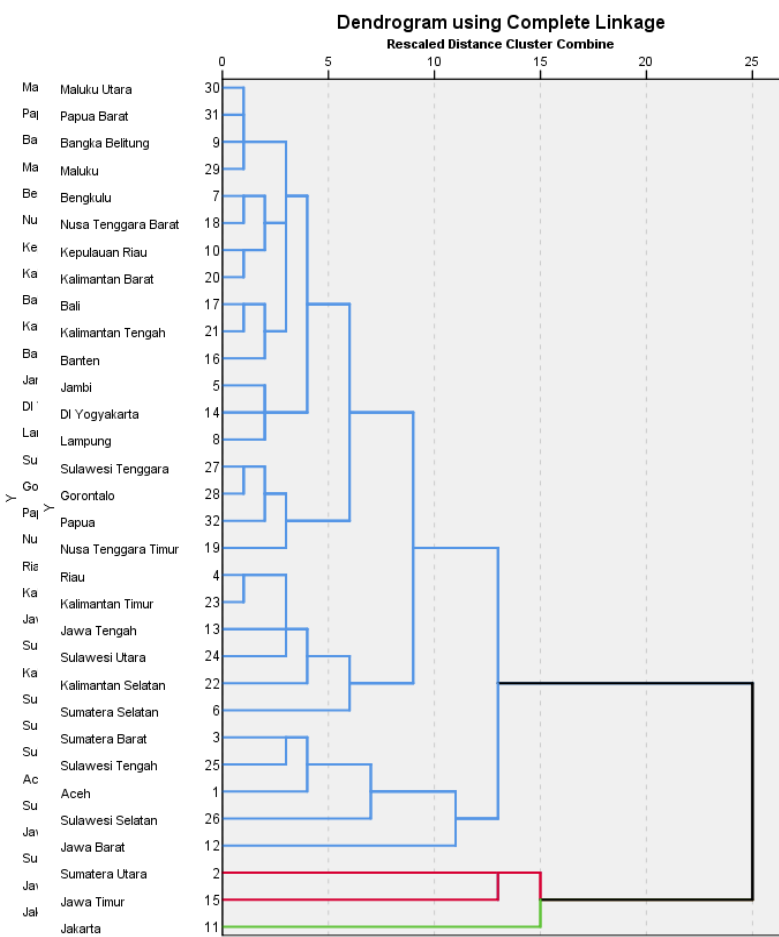

Gambar 2. Dendogram Complete Linkage

Gambar 2 tampak bahwa provinsi yang tergabung dalam tiga gerombol dituliskan dalam tabel 2.

Tabel 2. Pengelompokan Provinsi dengan Metode Complete Linkage

\begin{tabular}{|c|l|l|}
\hline Kelompok & \multicolumn{2}{|c|}{ Anggota Kelompok } \\
\hline \multirow{4}{*}{1} & Aceh & Nusa Tenggara Timur \\
\cline { 2 - 3 } & Sumatera Barat & Kalimantan Barat \\
\cline { 2 - 3 } & Riau & Kalimantan Tengah \\
\cline { 2 - 3 } & Jambi & Kalimantan Selatan \\
\cline { 2 - 3 } & Sumatera Selatan & Kalimantan Timur \\
\cline { 2 - 3 } & Bengkulu & Sulawesi Utara \\
\cline { 2 - 3 } & Lampung & Sulawesi Tengah \\
\cline { 2 - 3 } & Bangka Belitung & Sulawesi Selatan \\
\cline { 2 - 3 } & Kepulauan Riau & Sulawesi Tenggara \\
\cline { 2 - 3 } & Jawa Barat & Gorontalo \\
\cline { 2 - 3 } & Jawa Tengah & Maluku \\
\cline { 2 - 3 } & DI Yogyakarta & Maluku Utara \\
\cline { 2 - 3 } & Banten & Papua Barat \\
\cline { 2 - 3 } & Bali & Papua \\
\cline { 2 - 3 } & Nusa Tenggara & \\
& Barat & \\
\hline 2 & Sumatera Utara & \\
\hline 3 & Jawa Timur & \\
\hline \multirow{2}{*}{3} & Jakarta & \\
\hline
\end{tabular}

Sumber : Data Sekunder (2018), diolah

\subsection{Pengelompokan Dengan Metode Average Linkage}

Pada metode Average Linkage menghitung jarak antar objek yang disebut sebagai jarak ratarata dimana jarak tersebut dihitung pada masingmasing gerombol. Berdasarkan persamaan (2.4) dilakukan perhitungan jarak antara gerombol $(30,31)$ dengan gerombol lain. Diberikan contoh perhitungan antara gerombol $(30,31)$ dengan gerombol 1,2, dan 3, yaitu.

$d_{(3031), 1}=\frac{d_{(301)}+d_{(311)}}{2}=\frac{2.624,32+2.477,76}{2}=2.551,04$

$d_{(3031), 2}=\frac{d_{(302)}+d_{(312)}}{2}=\frac{7.983,40+7.904,59}{2}=7.944,00$

$d_{(3031), 3}=\frac{d_{(303)}+d_{(313)}}{2}=\frac{2.971,25+2.797,79}{2}=2.884,52$

Demikian seterusnya, proses perhitungan dilakukan dengan cara yang sama sehingga semua gerombol tergabung dalam tiga gerombol seperti tampak pada gambar 3 sebagai berikut.

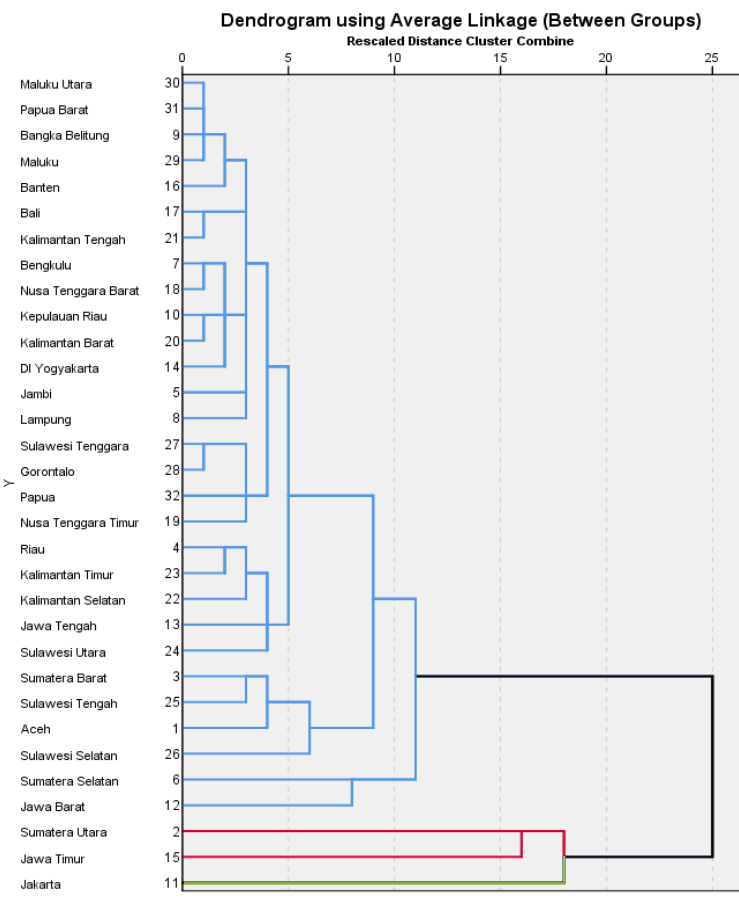

Gambar 3. Dendogram Average Linkage

Pada gambar 3 dapat dilihat bahwa hasil pengelompokan pada metode Average Linkage disajikan dalam tabel 3 . 
Tabel 3. Pengelompokan Provinsi dengan Metode Average Linkage

\begin{tabular}{|l|l|l|}
\hline Kelompok & Anggota Kelompok & \multicolumn{2}{|l|}{} \\
\hline \multirow{4}{*}{1} & Aceh & NTT \\
\cline { 2 - 3 } & Sumatera Barat & Kalimantan Barat \\
\cline { 2 - 3 } & Riau & $\begin{array}{l}\text { Kalimantan } \\
\text { Tengah }\end{array}$ \\
\cline { 2 - 3 } & Jambi & $\begin{array}{l}\text { Kalimantan } \\
\text { Selatan }\end{array}$ \\
\cline { 2 - 3 } & Sumatera Selatan & Kalimantan Timur \\
\cline { 2 - 3 } & Bengkulu & Sulawesi Utara \\
\cline { 2 - 3 } & Lampung & Sulawesi Tengah \\
\cline { 2 - 3 } & Bangka Belitung & Sulawesi Selatan \\
\cline { 2 - 3 } & Kepulauan Riau & $\begin{array}{l}\text { Sulawesi } \\
\text { Tenggara }\end{array}$ \\
\cline { 2 - 3 } & Jawa Barat & Gorontalo \\
\cline { 2 - 3 } & Jawa Tengah & Maluku \\
\cline { 2 - 3 } & DI Yogyakarta & Maluku Utara \\
\cline { 2 - 3 } & Banten & Papua Barat \\
\cline { 2 - 3 } & Bali & Papua \\
\cline { 2 - 3 } & NTB & \\
\hline 2 & Sumatera Utara & \\
\hline 3 & Jawa Timur & Jakarta \\
\hline
\end{tabular}

Sumber : Data Sekunder (2018), diolah

\subsection{Pengelompokan Dengan Metode K-Means}

Banyaknya gerombol yang ingin dibentuk dengan metode K-Means pada penelitian ini adalah tiga. Sehingga terdapat tiga buah centroid (pusat gerombol) dimana $c_{1}$ (centroid pertama), $c_{2}$ (centroid kedua), $c_{3}$ (centroid ketiga) dengan bantuan SPSS, nilai centroid dapat diliat pada tampilan initial cluster center pada tabel 4.

Tabel 4. Initial Cluster Center

\begin{tabular}{|l|c|c|c|}
\hline \multicolumn{4}{|c|}{ Initial Cluster Centers } \\
\hline \multirow{2}{*}{$\begin{array}{l}\text { Jenis } \\
\text { Kejahatan }\end{array}$} & 1 & 2 & 3 \\
\hline & 69 & 49 & 23 \\
\hline X1 & 1.601 & 688 & 167 \\
\hline X2 & 404 & 496 & 0 \\
\hline X3 & 1.324 & 491 & 52 \\
\hline X4 & 70 & 56 & 18 \\
\hline X5 & 210 & 195 & 64 \\
\hline X6 & 67 & 17 & 2 \\
\hline X7 & 1.642 & 854 & 69 \\
\hline X8 & 5.569 & 7.523 & 27 \\
\hline X10 & 5.969 & 1.693 & 36 \\
\hline X11 & 2.432 & 666 & 16 \\
\hline X12 & 52 & 112 & 35 \\
\hline
\end{tabular}

Sumber : Data Sekunder (2018), diolah

Sehingga diperoleh $c_{1}$ merupakan nilai dari tiap variabel untuk Provinsi Jakarta, $c_{2}$ merupakan nilai dari tiap variabel untuk Provinsi Jawa Timur, $c_{3}$ merupakan nilai dari tiap variabel untuk Provinsi Maluku Utara dengan nilai masing-masing seperti pada tabel 5 .

Perhitungan jarak setiap objek dengan $c_{1}, c_{2}$, dan $c_{3}$ menggunakan persamaan Jarak Euclidean. Demikian seterusnya sehingga proses ini memperoleh nilai centroid terbaru yang sama dengan final cluster centers output dari SPSS diuraikan dalam tabel 5 sebagai berikut.

Tabel 5. Final Cluster Center

\begin{tabular}{|l|c|c|c|}
\hline \multicolumn{4}{|c|}{ Final Cluster Centers } \\
\hline \multirow{2}{*}{ Jenis } & \multicolumn{3}{|c|}{ Cluster } \\
\cline { 2 - 4 } Kejahatan & 1 & 2 & 3 \\
\hline X1 & 69 & 105 & 34 \\
\hline X2 & 1601 & 1824 & 313 \\
\hline X3 & 404 & 1620 & 595 \\
\hline X4 & 1324 & 246 & 316 \\
\hline X5 & 70 & 121 & 44 \\
\hline X6 & 210 & 98 & 111 \\
\hline X7 & 67 & 48 & 7 \\
\hline X8 & 1642 & 1500 & 751 \\
\hline X9 & 5569 & 6557 & 706 \\
\hline X10 & 5969 & 1881 & 604 \\
\hline X11 & 2432 & 1838 & 494 \\
\hline X12 & 52 & 84 & 37 \\
\hline
\end{tabular}

Sumber : Data Sekunder (2018), data diolah

Dapat dilihat nilai ketiga centroid baru tersebut sudah tetap atau tidak mengalami perubahan, maka proses pengelompokan berhenti. Sehingga untuk kelompok yang terbentuk pada tabel 6 .

Tabel 6. Pengelompokan Provinsi dengan Metode K-Means

\begin{tabular}{|c|l|l|}
\hline Kelompok & \multicolumn{2}{|c|}{ Anggota Kelompok } \\
\hline 1 & Jakarta & \\
\hline 2 & Sumatera Utara & Jawa Timur \\
\hline \multirow{4}{*}{} & Aceh & NTT \\
\cline { 2 - 3 } & Sumatera Barat & Kalimantan Barat \\
\cline { 2 - 3 } & Riau & Kalimantan Tengah \\
\cline { 2 - 3 } & Jambi & Kalimantan Selatan \\
\cline { 2 - 3 } & Sumatera Selatan & Kalimantan Timur \\
\cline { 2 - 3 } & Bengkulu & Sulawesi Utara \\
\cline { 2 - 3 } & Lampung & Sulawesi Tengah \\
\cline { 2 - 3 } & Bangka Belitung & Sulawesi Selatan \\
\cline { 2 - 3 } & Kepulauan Riau & Sulawesi Tenggara \\
\cline { 2 - 3 } & Jawa Barat & Gorontalo \\
\cline { 2 - 3 } & Jawa Tengah & Maluku \\
\cline { 2 - 3 } & DI Yogyakarta & Maluku Utara \\
\cline { 2 - 3 } & Banten & Papua Barat \\
\cline { 2 - 3 } & Bali & Papua \\
\cline { 2 - 3 } & NTB & \\
\hline
\end{tabular}

Sumber : Data Sekunder (2018), diolah

\subsection{Pemilihan Metode Terbaik}

Pada tahap ini akan dilakukan pemilihan metode terbaik pada metode Single Linkage, 
Complete Linkage, Average Linkage, dan KMeans yang telah dijelaskan sebelumnya telah diperoleh tiga kelompok atau gerombol. Hasil perhitungan nilai rasio $s_{w}$ terhadap $s_{b}$ pada masing-masing metode dapat dilihat pada tabel 7.

Tabel 7. Perbandingan Nilai Rasio Simpangan Baku (s)

\begin{tabular}{|l|l|l|}
\hline No & Metode & $\begin{array}{l}\text { Nilai Simpangan } \\
\text { Baku }(s)\end{array}$ \\
\hline 1 & Single Linkage & 0,18 \\
\hline 2 & Complete Linkage & 0,34 \\
\hline 3 & Average Linkage & 0,34 \\
\hline 4 & K-Means & 0,34 \\
\hline
\end{tabular}

Sumber : Data Sekunder (2018), data diolah

\subsection{Analisis Biplot}

Setelah terbentuknya kelompok-kelompok provinsi, maka akan dilihat vektor jenis akan dilihat vektor jenis kejahatan mana yang memberikan sumbangan keragaman relative besar terhadap masing-masing kelompok provinsi yang selanjutnya disebut sebagai peubah penciri dari masing-masing kelompok provinsi tersebut. Untuk itu akan dilakukan pembentukan plot uda dimensi, dimana data yang digunakan merupakan data nilai rata-rata dari setiap jenis kejahatan yang dimiliki masingmasing kelompok.

Untuk memperoleh plot dua dimensi dari masing-masing kelompok provinsi dan jenis kejahatan, maka langkah awal yang perlu dilakukan adalah mencari titik koordinat dari masing-masing kelompok provinsi dan jenis kejahatan. Koordinat dari masing-masing kelompok provinsi dapat diperoleh dari matriks $G$, sedangkan koordinat dari masing-masing jenis kejahatan dapat diperoleh dari matriks $H$.

Dengan menggunakan bantuan program $R$, maka diperoleh matriks $G$ yang memuat skor komponen dari dua komponen utama dari data sebagai berikut.

Tabel 9. Skor Komponen 1 dan Komponen 2

\begin{tabular}{|l|l|l|}
\hline Kelompok & $\begin{array}{l}\text { Skor } \\
\text { Komponen 1 }\end{array}$ & $\begin{array}{l}\text { Skor } \\
\text { Komponen 2 }\end{array}$ \\
\hline Kelompok 1 & -0.8159858 & 0.02887711 \\
\hline Kelompok 2 & 0.3829846 & -0.72110296 \\
\hline Kelompok 3 & 0.4330012 & 0.69222585 \\
\hline
\end{tabular}

Sumber : Data Sekunder (2018), data diolah
Untuk memperoleh matriks $H$ dilakukan dengan hal yang sama dengan menggunakan bantuan $R$, maka diperoleh matriks $H$ yang memuat dua vektor eigen pertama yang merupakan titik-titik koordinat dari masingmasing jenis kejahatan disajikan pada tabel 10 sebagai berikut.

Tabel 10. Tabel Vektor Eigen 1 dan Vektor Eigen 2

\begin{tabular}{|l|l|l|}
\hline $\begin{array}{l}\text { Jenis } \\
\text { Kejahatan }\end{array}$ & Vektor eigen 1 & Vektor eigen 2 \\
\hline X1 & 53.804002 & -81.14962 \\
\hline X2 & 1140.852913 & -1647.21868 \\
\hline X3 & 785.193724 & -1617.65098 \\
\hline X4 & -72.909832 & 349.98699 \\
\hline X5 & 59.065752 & -94.07172 \\
\hline X6 & -9.182813 & 138.29711 \\
\hline X7 & 30.215811 & -44.93738 \\
\hline X8 & 554.163239 & -933.05773 \\
\hline X9 & 4690.051125 & 1201.00817 \\
\hline X10 & 886.435541 & -296.70132 \\
\hline X11 & 984.700445 & -1692.63612 \\
\hline X12 & 39.074529 & 38.23995 \\
\hline
\end{tabular}

Sumber : Data Sekunder (2018), data diolah

Setelah diperoleh koordinat dari masingmasing kelompok provinsi dan jenis kejahatan, maka selanjutnya dibentuk plot untuk masingmasing kelompok dan jenis kejahatannya. Berikut ini adalah penggambaran biplot yang menampilkan titik untuk setiap kelompok provinsi dan jenis kejahatan.

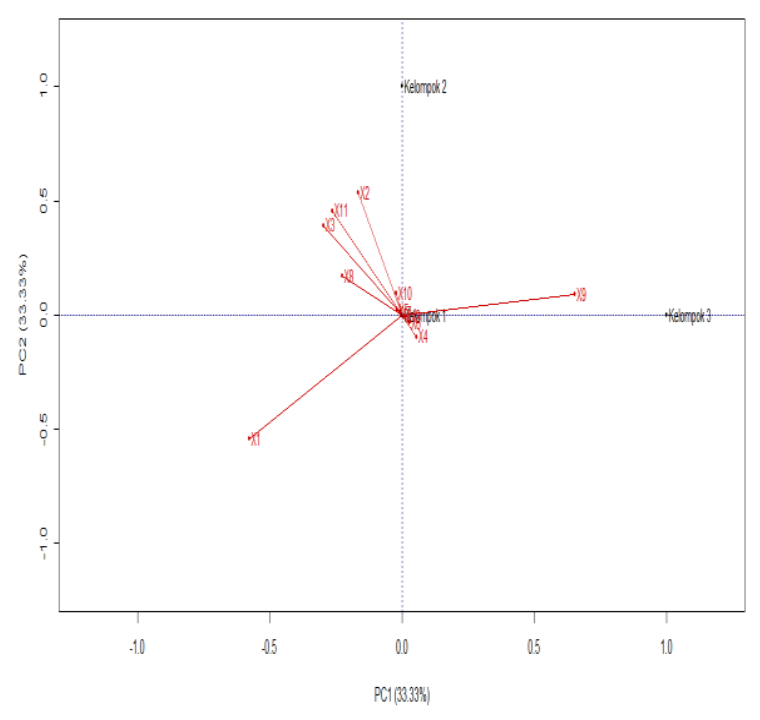

Gambar 4. Hasil Pemetaan Biplot 
Pada gambar 4 merupakan hasil pengelohan dari analisis yang memliki keragaman data atau ukuran kesesuaian biplot yang diterangkan oleh dua sumbu utama biplot yaitu sebersar 66,66\%, dimana sumbu pertama (PC1) mampu menerangkan keragaman data sebesar 33,33\% dan sumbu kedua (PC2) mampu menerangkan keragaman $33,33 \%$. Hal ini menunjukkan bahwa analisis biplot hanya mampu menjelaskan informasi sebersa $66,66 \%$ dari keseluruhan data dan terdapat kehilangan informasi sebesar $33,34 \%$.

Untuk mengetahui jenis kejahatan yang menjadi penciri dari masing-masing kelompok provinsi maka akan dilakukan proyeksi ortogonal dari masing-masing kelompok provinsi terhadap setiap vektor jenis kejahatan untuk mengetahui panjang proyeksi verktor dimana semakin besar panjang proyeksinya hal ini berarti semakin besar juga ciri yang diwakili kelompok provinsi berdasarkan peubah atau jenis kejahatan yang bersesuaian.

Tabel 11. Panjang Proyeksi Vektor

\begin{tabular}{|c|r|r|r|}
\hline $\begin{array}{c}\text { Jenis } \\
\text { Kejahatan }\end{array}$ & Kelompok 1 & $\begin{array}{c}\text { Kelompok } \\
2\end{array}$ & Kelompok 3 \\
\hline X1 & -0.4749777 & 0.8126385 & -0.3376608 \\
\hline X2 & -0.4883362 & 0.8108654 & -0.3225292 \\
\hline X3 & -0.3822941 & $\mathbf{0 . 8 1 5 9 5 7 8}$ & -0.4336637 \\
\hline X4 & $\mathbf{0 . 1 9 4 6 8 4 9}$ & -0.7840544 & 0.5893695 \\
\hline X5 & -0.4583579 & 0.814355 & -0.3559971 \\
\hline X6 & 0.0828754 & -0.7448926 & 0.6620172 \\
\hline X7 & -0.4792744 & 0.8121073 & -0.3328329 \\
\hline X8 & -0.4415097 & 0.8155673 & -0.3740577 \\
\hline X9 & -0.7833159 & 0.1921283 & 0.5911877 \\
\hline X10 & -0.782957 & 0.5920621 & 0.1908949 \\
\hline X11 & -0.4352816 & 0.8158861 & -0.3806045 \\
\hline X12 & -0.5629858 & -0.2306449 & $\mathbf{0 . 7 9 3 6 3 0 8}$ \\
\hline
\end{tabular}

Sumber : Data Sekunder (2018), data diolah

Berdasarkan tabel 11 dapat dilihat bahwa kelompok 1 memiliki pangjan proyeksi vektor pada jenis kejahatan $\mathrm{X} 4$ atau jenis kejahatan kekerasan dalam rumah tangga (KDRT), sehingga untuk peubah penciri pada kelompok 1 yaitu jenis kejahatan KDRT. Kemudian untuk peubah penciri setiap kelompok akan dirangkum dalam tabel 12.
Tabel 12. Peubah Penciri Setiap Kelompok

\begin{tabular}{|c|l|}
\hline Kelompok & Peubah Penciri \\
\hline 1 & $\begin{array}{l}\text { Jenis Kejahatan Kekerasa Dalam } \\
\text { Rumah Tangga (X4) }\end{array}$ \\
\hline 2 & $\begin{array}{l}\text { Jenis Kejahatan Penganiayaan Ringan } \\
(\mathrm{X} 3)\end{array}$ \\
\hline 3 & Jenis Kejahatan Korupsi (X12) \\
\hline
\end{tabular}

Sumber : Data Sekunder (2018), data diolah

\section{KESIMPULAN DAN SARAN}

\subsection{Kesimpulan}

Berdasarkan hasil penelitian yang dilakukan pada bab sebelumnya bahwa untuk pengelompokan tingkat kriminalitas dengan metode Agglomerative dan K-Means pada 32 provinsi dapat disimpulkan untuk metode terbaik dalam pengelompokan tingkat kriminalitas yaitu metode Single Linkage.

Terdapat tiga kelompok dalam metode Single Linkage. Kelompok pertama terdiri dari Provinsi Aceh, Sumatera Barat, Riau, Jambi, Sumatera Selatan, Bengkulu, Lampung, Kepulauan Riau, Jakarta, Jawa Barat, Jawa, DI Yogyakarta, Banten, Bali, NTB, NTT, Kalimantan Barat, Kalimantan Tengah, Kalimantan Selatan, Kalimantan Timur, Sulawesi Utara, Sulawesi Tengah, Sulawesi Selatan, Sulawesi Tenggara, Gorontalo, Maluku, Maluku Utara, Papua Barat, dan Papua. Sedangkan untuk kelompok kedua dan ketiga yaitu Provinsi Sumatera Utara dan Provinsi Jawa Timur. Kemudian untuk peubah penciri pada ketiga kelompok tersebut yaitu kelompok pertama perubah pencirinya adalah jenis kejahatan KDRT sedangkan untuk kelompok kedua peubah pencirinya yaitu jenis kejahatan penganiayaan ringan dan untuk kelompok ketiga peubah pencirinya adalah jenis kejahatan korupsi.

\subsection{Saran}

Pada penelitian ini hanya mengkaji tentang empat metode pengelompokan dalam analisis gerombol yaitu Single Linkage, Complete Linkage, Average Linkage, dan metode K-Means dengan penentuan jumlah kelompok adalah tiga kelompok. Bagi peneliti yang ingin melanjutkan tentang analisis gerombol dapat menggunakan 
metode-metode analisis gerombol yang lain seperti metode Ward dan Two Step Cluster sebagai perbandingan.

\section{DAFTAR PUSTAKA}

Barakbah, Ali \& Arai, Kohei. 2004. Determining Constraints Of Moving Variance to Find Global Optimum and Make Automatic Clustering. Industrial Electronics Seminar, 409-413.

Bunkers WJ, et al. 1996. Definition of Climate Regions in the Northern Plains Using an Objective Cluster Modification Technique. J.Climate 9:130-146.

Everitt, Brian.S.et.al. 2011. Cluster Analisis. $5^{\text {th }}$ Edition. United Kingdom. John Wiley and Son,Ltd.

Gudono. 2011. Analisis Data Multivariat. Edisi Pertama. Yogyakarta: BPFE.

Jollife, I.T 2002. Principal Component Analysis. Springer-verlag. New York.

Johnson, R.A.\&.Dean.W.Wichern. 2007. Applied Multivariate Statitical Analysis. Sixth Edition. United State of America: Pearson Education Inc.

Rencher, A.C. 2002. Methods of Multivariate Analysis Second Edition. New Yowk: John Wiley And Son,Inc. 